\title{
Productivity and the Dollar/Euro Real Exchange Rate Over the 1985-2007 Period
}

Ordean Olson, Nova Southeastern University, USA

\begin{abstract}
This paper examines the evidence for a productivity- based model of the dollar/euro real exchange rate for the period 1985-2007. Cointegrating relationships between the real exchange rate and productivity, real price of oil and government spending are estimated using the Johansen and StockWatson procedures. The findings show that each percentage point in the U.S.-Euro area productivity differential results in a three and one-half percentage point real change in the dollarleuro valuation. This finding is robust to the estimation methodology, the variables included in the regression, and the sample period. I conjecture that productivity-based models cannot explain the observed patterns with the standard set of assumptions and describe cases in which the models can be reconciled with the observed data.
\end{abstract}

Keywords: Exchange rate, productivity, euro, U.S. dollar, cointegration

\section{INTRODUCTION}

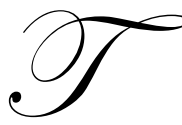

he euro depreciated appreciably against the dollar during the period 1995-2002. This decline has often been associated with relative productivity changes in the United States and the euro area over this time period. During this span in particular, average labor productivity accelerated in the United States, while it decelerated in the euro area. Economic theory suggests that the equilibrium real exchange rate will appreciate after an actual or expected shock in average labor productivity in the traded goods sector. Such an equilibrium appreciation may be increased in the medium term by demand side effects. Thus, productivity increases raise expected income, which leads to an increased demand for goods. However, the price of goods in the traded sector is constrained by international competition. By contrast, in the non-traded sector where industries are not subject to the same competition, goods prices tend to vary widely and independently across countries.

The work of Harrod (1933), Balassa (1964), and Samuelson (1964) showed that productivity growth will lead to a real exchange rate appreciation only if it is concentrated in the traded sector of an economy. Productivity growth that has been equally strong in the traded and non-traded sectors will have no effect on the real exchange rate.

This paper analyses the impact of relative productivity developments in the United States and the euro area on the dollar/euro exchange rate. This paper then provides evidence on the long-run relationship between the real dollar/euro exchange rate and productivity measures with and without the oil and government spending variables. Importantly, to the extend that traders in foreign exchange markets act in response to the available productivity data more than ever stresses the importance of reliable models.

From the first to the second half of the 1990's, average productivity accelerated in the United States, while it decelerated in the euro area. This relationship has stimulated a discussion on the relationship between productivity and appreciation of the dollar during this time period. Also of equal importance is the depreciation of the dollar during the early part of the 2000's (United States productivity increased slowly while the euro area productivity increased more rapidly). Bailey and Wells (2001), for instance, argue that a structured improvement in U.S. productivity increased the rate of return on capital and triggered substantial capital flows in the United States, which might explain, in part, the appreciation of the U.S. dollar during the early part of the 2000's. Tille and Stoffels (2001) confirm empirically that developments in relatively labor productivity can account for part of the 
change in the external value of the U.S. dollar over the last three decades. Alquist and Chinn (2002) argue in favor of a robust correlation between the euro area United States labor productivity differential and the dollar/euro exchange rate. This would explain the largest part of the euro's decline.

This paper argues that the euro's persistent weakness in the 1995-2001 period and its strength during the 2001-2007 period can be partly explained by taking into consideration productivity differentials. In particular, this paper analyses, in detail, the impact of relative productivity developments in the United States and the euro area on the dollar/euro exchange rate.

This study is organized as follows: The first part is the introduction. The next section explains the relationship between productivity advances and the real exchange rate from a theoretical perspective. Section 3 describes the data used in the empirical analysis. Section 4 analyses the relationship between the euro area/U.S. productivity differentials and the dollar/euro real exchange rate. Section 5 summaries the results and conclusions.

\section{THE REAL EXCHANGE RATE AND PRODUCTIVITY DEVELOPMENTS}

The theoretical relationships that link fundamentals to the real exchange rate in the long-run center around the Balassa-Samuelson model, portfolio balance considerations as well as the uncovered (real) interest rate parity condition. This paper will focus on the role of productivity differentials in the determination of the dollar/euro exchange rate.

According to the Balassa-Samuelson framework, the distribution of productivity gains between countries and across tradable and non-tradable goods sectors in each country is important for assessing the impact of productivity advances on the real exchange rate. The intuition behind the Balassa-Samuelson effect is rather straight-forward: assuming, for instance of simplicity, that productivity in the traded goods sector increases only in the home country, marginal costs will fall for domestic firms in the traded-goods sector. This leads (under the perfect competition condition) to a rise in wages in the traded goods sector at given prices. If labor is mobile between sectors in the economy, workers shift from the non-traded sector to the traded sector in response to the higher wages. This triggers a wage rise in the non-traded goods sector as well, until wages equalize again across sectors. However, since the increase in wages in the non-traded goods sector is not accompanied by productivity gains, firms need to increase their prices, which do not jeopardize the international price competitiveness of firms in the traded goods sector.

Accordingly, there should be a proportional link between relative prices and relative productivity. Labor productivity, however, is also influenced by demand-side factors, though their effect should be of a transitory rather than of a permanent nature. In particular, as the productivity increase raised future income, and if consumers value current consumption more than future consumption, they will try to smooth their consumption pattern (Bailey and Wells 2001). This leads to an immediate increases demand for both traded and non-traded goods. The increase in demand for traded goods can be satisfied by running a trade deficit. The increased demand for non-traded goods, however, cannot be satisfied and will lead to an increase in prices of non-traded goods instead. Thus, demand effects lead to a relative price shift and thereby to a real appreciation.

Table 1 in the appendix suggests that the data are nonstationary. The empirical analysis, therefore, employs cointrgration tests as developed by Johansen (1995). In the present setting, some variables (such as the real interest rate differential) would theoretically be expected to be stationary, but appear to be near-integrated processes empirically. The presence of the cointegration relationships is tested in a multivariate setting.

The standard starting point for cointegration analysis is a linear dynamic system of variables with a maximum lag length of $\mathrm{k}$ periods over the sample $\mathrm{t}=\mathrm{I}, \ldots \mathrm{T}$, in the form of a vector autoregression model of order $\mathrm{k}$, which can be represented as the vector error-correction model (VECM).

$$
\Delta \mathrm{y}_{\mathrm{t}}=\varsigma\left[\beta \mathrm{u}_{1} \Phi_{1}\right] \mathrm{y}_{\mathrm{t}-1}+\Sigma(\mathrm{k}-1 \mathrm{i}=1)_{-\mathrm{I}} \Delta \mathrm{y}_{\mathrm{t}-\mathrm{I}}+\mathrm{Y}+\prod^{+} \ni_{\mathrm{t}}
$$


where $\mathrm{y}_{\mathrm{t}}$ is a ( $\mathrm{n} \mathrm{x}$ I vector) of the $\mathrm{n}$ variables of interest, here including the real exchange rate, productivity, the real price of oil, the real interest rate differential and relative government spending, $\square_{I}$ are the matrices of short-run coefficients, $\ni_{t}$ denotes a $(\mathrm{n} \mathrm{x} \mathrm{I})$ vector of white noise errors. As regards the other deterministic components, Doornik and Hendry (1999) show that including an unrestricted constant and a restricted trend mitigates chances of a mis-specification bias.

Following Johansen (1995), the model is estimated by maximum likelihood. The rank of the $n(x) n$ coefficient matrix $\Pi$ is central to this methodology, as it determines the number of cointegrating vectors. The estimate for $\beta$ is given by the $r$ eigenvectors of $\prod$.

\section{DATA FOR ADDITIONAL VARIABLES}

For the period prior to 1999, the real dollar/euro exchange rate (based on consumer prices) has been computed as a weighted geometric average of the bilateral exchange rates of the euro legacy currencies against the dollar. The rate of expected rate of inflation is proxied by the annual rate of inflation in the previous year. In addition, the model was estimated controlling for several other variables, as usually done in the literature, but only the real price of oil and the relative ratio of government spending to GDP appeared significant. As regards the real price of oil, its usefulness for explaining trends in real exchange rates is documented. For example, Amano and Van Norden (1998a and 1998b) found strong evidence of a long-term relationship between the real effective exchange rate of the U.S. dollar and the oil price. As regards government spending, the fiscal balance constitutes one of the key components of national saving. In particular, Frenkel and Mussa (1985) argued that a fiscal tightening causes a permanent increase in the net foreign asset position of a country, and consequently, an appreciation of its equilibrium exchange rate in the long term. This will occur provided that the fiscal consolidation is considered to have a permanent character.

\section{PRODUCTIVITY AND THE REAL DOLLAR-EURO EXCHANGE RATE}

This section presents evidence in favor of stable long-run relationships between the real dollar/euro exchange rate, the productivity measure, and the other variables. One model specification was estimated for the productivity measure. The sample covers the period from 1985 to 2008. Liklihood ratio tests in unrestricted VAR estimates suggest that the optimal lag length is two in the VAR in levels. This general model includes all variables discussed above as well as deterministic components. Within this general model, trace tests were carried out to determine the cointegration rank along with the deterministic specification. In the second step, coefficients that turned out insignificant in the cointegration vector were restricted to 0 .

The test statistics and estimated parameters for the final model are summarized in Tables 2 and 3 . They show the results of the cointegration tests. None of the inverse roots within a non-explosive framework lies outside the unit circles. According to standard critical values for the trace test, evidence for one cointegration vector was found in each specification at the 5\% level of significance. Standard misspecification tests on the residuals indicate that the model is well specified. Over all, the results suggest that it is reasonable to assume a single cointegration relationship between the variables of interest.

\section{EXPLAINING THE EURO DECLINE BY PRODUCTIVITY DEVELOPMENTS DURING 1995-2001 AND 2001-2007}

This study will show how much of the decline of the euro against the U.S. dollar can be attributed to relative changes in productivity in the United States and the euro area. While the estimation covers the period 19852007, the following analysis concentrates on two periods:

Period 1 (1995-2001) covers the U.S. dollar appreciation against the euro. Moreover, it encompasses the period during which the productivity revival in the United States has arguably taken place. Over this period, the dollar appreciated by almost $41 \%$.against the euro area currency. During the first three years (1998-2001) of the euro, it depreciated by almost $30 \%$ against the U.S. dollar. Chart 1 shows the impact of a change in relative productivity developments over these periods on the equilibrium real exchange rate. The contribution of the relative 
developments in productivity on the explanation of the depreciation of the euro against the U.S. dollar since 1995 is significant. However, these developments are far from explaining the entire euro decline. The productivity differential data results suggest a depreciation of the euro of almost $14 \%$ due to productivity developments during the period 1995-1998, and more than 30\% from the launch of the Euro in 2001 until 2007. Chart 2 shows the impact of a change in relative U.S. GDP and Euro GDP on the equilibrium dollar/euro real exchange rate. Period 2 (2001-2007) covers the U.S. dollar depreciation against the euro.

\section{IMPULSE RESPONSES}

Chart 3 displays the impulse responses of the GDP to a one standard deviation change in the dollar/euro exchange rate and showed the GDP of the economies of both the U.S. and the Euro area countries increased upon impact. The responses are significant at the $95 \%$ level. Chart 4 displays the impulse responses of the real exchange rate to the various one-standard deviation shocks. The results closely resemble those of Clarida and Galf (1992). Also note that the results are relatively robust with the individual impulse responses falling within the 5\% significant tests. The major impulse response of real exchange rates is found with respect to aggregate demand shock. For the exchange rate these shocks have a highly significant impact over the 10-year time periods and the correlation between these impulse responses is high. They show that productivity shocks have a very significant long-run impact on the dollar/euro exchange rate. This suggests the fundamental real factors are significant in the long-run fluctuations in real exchange rates.

\section{DISCUSSION OF THE RESULTS}

Evidently, productivity is not the only variable affecting the real exchange rate in the model specified. The other fundamentals identified also affected the dollar/euro exchange rate. In particular, the surge in oil prices since early 1999 seems to have contributed to the weakening of the euro, while the real interest rate differential and relative government spending have had only marginal effects on the dollar/euro exchange rate.

The magnitude of the long-run impact of changes in the real price of oil on the dollar/euro exchange rate is certainly non-negligible. Applying the estimated elasticities strictly to the rise in (real) oil prices between 1998 and 2001, the model indicates, on average, that the equilibrium euro depreciation related to oil prices developments could have been around 16\%, which would explain almost $39 \%$ of the actual euro depreciation. These are based on long-term relationships. For the period 2001 to 2007, the magnitude of the long-run impact of changes in the real price of oil on the dollar would explain almost $30 \%$ of the actual euro appreciation. This data is not shown but is available.

Overall, the model is surrounded by significant uncertainty, reflecting the inherent difficulty of modeling exchange rate behavior. While we find that in 1999-2001 the euro has traded well below the central estimates derived from these specifications, this uncertainty precludes any quantification of the precise amount of over or under valuation at any point in time. This point is also made clear in Detken and Dieppo (2002), who employ a wide range of modeling strategies and show that the deviation from the estimated equilibrium differs widely across models and is surrounded by some non-negligible uncertainty. Moreover, it broadly reinforces the results provided by Maeso-Fernandez and Osbat (2001) who concentrate on only one modeling approach equivalent to the one used in this project. They also find various reasonable but non-encompassing specifications leading to different exchange rate equilibria, again suggesting a very cautious interpretation of the magnitude of over/under valuation.

This paper provides evidence on the long-run relationship between the real dollar/euro exchange rate and productivity measures, controlling for the real interest rate differential, the real price of oil, and relative government spending. Table 4 shows the test results and t-values of the study.

In this paper, the results imply that the productivity measure can explain only about $18 \%$ of the actual amount of depreciation of the euro against the U.S. dollar for the period 1995-2001. This outcome is confirmed by a specification in this study. The results also imply that the productivity can explain only about $30 \%$ of the appreciation of the euro during the period 2001-2007. 
With regard to other exchange rate fundamentals, the surge in oil prices in 1999-2000 and 2005-2007 might have weighted on the dollar/euro exchange rate. From an equilibrium perspective, however, the fact that oil prices peaked in 2000 and 2008 suggests that a cautious interpretation of the implied equilibrium exchange rates is warranted. Overall, two main results can be reconciled: firstly, the euro has traded well below the central estimates derived from these specifications in 1998-2001, and secondly, relative productivity developments appear for only part of the euro appreciation for the period 2001-2007.

\section{AUTHOR INFORMATION}

Dr. Olson is presently teaching at Nova Southeastern University Huizenga School of Business \& Entrepreneurship teaching finance and economics as well as servicing as the Banking and Finance Coordinator. Dr. Olson also teaches at the graduate school teaching financial management and managerial economics at locations throughout the United States, Japan, Jamaica, Columbia, Israel, and the Bahamas. He recently conducted an international financial seminar for the faculty of La Universidad Autonoma De Bucaramanga in Bucaramanga, Columbia. Dr. Olson has conducted personal finance seminars for the Miami Dolphins football tem sponsored by the National Football League. He has presented papers at Cambridge and Oxford Universities in England. He completed residence at Oxford University as a member of the Oxford Round Table in 2004. Dr. Olson is active in the community serving on the Academy of Finance Advisory Committee on the Broward County School Board

Dr. Olson has twenty-five years experience in the field of financial management including the position of senior loan officer and V.P. with Security Pacific National Bank. He has held senior management positions with Fortune 500 companies. His background includes the position of a senior negotiator for the State of California.

He specializes in the field of Financial Management and International Finance and has written numerous papers on International Finance and is published in the field of monetary and fiscal policy under different exchange rate regimes and optimum currency areas. Dr. Olson competes as a professional golfer on the Senior Professional Golf (PGA) Tour during the summer months. His sports background includes playing basketball and baseball at San Diego State University and playing three years of professional baseball. He enjoys hunting and is a member of the National Rifle Association and an expert rifleman.

He is a decorated Korean War Veteran having served with the U.S Air Force flying combat missions during the Korean War.

\section{REFERENCES}

1. Alberola, E.S.G. Cervero, H. Lopez and A. Ubide (1999) "Global Equilibrium Exchange Rates: Euro, Dollar, Ins, Outs, and other Major Currencies in a Panel Cointegration Framework”, IMF Working Paper, 173.

2. Alquist, R. and M. D. Productivity and the Euro-Dollar Exchange Rate Puzzle”, NBER Working Paper, 8824.

3. Amano, R. A. and S. Van Norden (1998a) "Exchange Rates and Oil Prices" Review of International Economics 6,4, 683-694.

4. Amano, R. A. and .Van Norden (1998b) "Oil Prices and the Rise and Fall of the U.S. Real Exchange Rate", Journal of International Money and Finance, 17, 299-316.

5. Asea, P. K. and M. W. Corden (1994) “The Balassa-Samuelson Model: An Overview”, Review of International Economics, 2,3, 191-200.

6. Bailey, A. S. and S. Wells (2001) "Capital Flows and Exchange Rates" Bank of England Quarterly Bulletin, Autumn, 310-318.

7. Bergstrand, J. H. (1991) "Structural Determination of Real Exchange Rates and National Price levels: Some Empirical Evidence", American Economic Review, 81, 1, 325-334.

8. Blaug, M. (1997) "Economic Theory in Retrospect", Cambridge University Press.

9. Canzoneri, M.B., R. Cumby and B. Diba (1999) "Relative Labor Productivity and the Real Exchange Rate in the Long-Run: Evidence for a Panel of OECD Countries", Journal of International Economics, 47, 245 266. 
10. Chinn, M.D., R. Alquist (2000) “Tracking the Euro's Progress", International Finance, 3, 357-373.

11. Chinn, M.D., and L. Johnson (1997) "Real Exchange Rate Levels, Productivity and Demand Shock Evidence from a Panel of 14 Countries", IMF Working Paper, 66.

12. Chow, G.C., and A. Lin (1971) "Best Linear Unbiased Interpolation, Distribution and Extrapolation of a Time Series by Related Series", Review of Economics and Statistics, 54, 372-375.

13. Clostermann, J. and B. Schnatz (2006) "The Determinants of the Euro-Dollar Exchange Rate Synthetic Fundamentals and a Non-Existing Currency", Konjunkturpolitik, Applied Economics Quarterly, 46, 207230.

14. De Gregorio, J.A., and Giovannini, H. Wolf (1994) "International Evidence on Tradables and Nontradables Inflation", European Economic Review, 38, 1225-1244.

15. Detkin, C.A. Dieppe, J. and L. Oxland (eds): Practical Issues in Cointegration Analysis, Oxford, 117-156.

16. Doornik, J.A., D.F. Hendry and B. Nielsen (1999) "Inference in Cointegrating Models: UK M1 Revisited", M. McAleer and L. Oxley (eds): Practical Issues in Cointegration Analysis, Oxford, 117-156.

17. European Central Bank (2001) "New Techniques and Productivity Growth in the Euro Area", Monthly Bulletin, July, 37-48.

18. European Central Bank (2002) "Econmomic Fundamenntals and the Exchange Rate of the Euro", Monthly Bulletin, January, 41-53.

19. Fisher, C. (2002) "Real Currency Appreciation in EU Accession Countries: Balassa-Samuelson and Investment Demand", Deutsche Bendesbank Discussion Paper 19.02.

20. Frenkel, J. and Mussa, M. (1995) “Asset Markets, Exchange Rates and the Balance of Payments”, R. Jones and P. Kenen (eds): Handbook of International Economics, 2 North-Holland.

21. Johansen, S. (1995) Likelihood-based Inference in Cointegrated Vector Auto-Regresssive Models, Jorgenson, D. W. and K. J. Stiroh (2000) "Raising the Speed Limit: U.S. Economic Growth in the Information Age", Brookings Papers on Economic Activity, I, 125-211.

22. Lorenzen, H.P. and N. Thygesen (2000) "The Relation Between the Euro and the Dollar", paper presented at the EPRU Conference, Copenhagen.

23. MacFonald, R. (1998) "What Determines Real Exchange Rates? The Long and the Short of it". Journal of International Financial Markets, Institutions and Money, 8, 2, 117-153.

24. MacDonald. R., and J. Nagayasu (2000) "The Long-Run Relationship Between the Real Exchange Rates and Interest Rate Differentials: A Panel Study" IMF Staff Papers, 47 116-128.

25. Maeso-Fernandez, F.C. Osbat and B. Schnatz (2001) "Determinants of the Euro Real Effective Exchange Rate: A. Beer/Peer approach", ECB Working Paper, 85.

26. McGuckin, R. and B. van Ark (2002) Performance 2001: Productivity, Employment, and Income in the World's Economics, New Your and Brussels.

27. Pesaran, M. H., R. P. Smith (1999) “Structural Analysis of Cointegrating VAR's”, M. McAleer and L. Oxley (eds): Practical Issues in Cointegrating Analysis, Oxford, 55-89.

28. Reimers, H. E. (1992) "Comparisons jog tests of Multivariate Cointegration", Statistical Papers, 33, 335339.

29. Rogoff, K. (1991) "Oil, Productivity, Government Spending and the Real Yen-Dollar Exchange Rate", Center for Pacific Basin Monetary and Economics Studies, Federal Reserve bank of San Francisco, Pacific Basin Working Paper Series 91-06.

30. Schlnatz, B., Focco Vijselaar and Chiara Osbat (2003) "Productivity and the (Synthetic) Euro-Dollar Exchange Rate", European Central Bank Working Paper Series", April 2003.

31. Stein, J. (2001) "The Equilibrium Value of the Euro/\$ U.S. Exchange Rate: An Evaluation of Research", CESIFO Working Paper, 825, Munich.

32. Tille, C., N. Stoffels, and O. Gorgatchev (2001) "To What Extent Does Productivity Drive the Dollar?", Current Issues in Economics and Finance, Federal Reserve Bank of New York, 7,8. 1-6.

33. Uni,Hiroyuki (2007) "Export-based Productivity increase and Exchange Rate Regimes in East Asia and Europe", The Kyoto Economic Review, 76(1), 117-138 (June 2007)

34. Vuselaar, Flew. and R. M. Albers (2002) "New Technologies and Productivity Growth in the Euro Area", ECB Working Paper, 122. 
Table 1

ADF Unit Root Tests

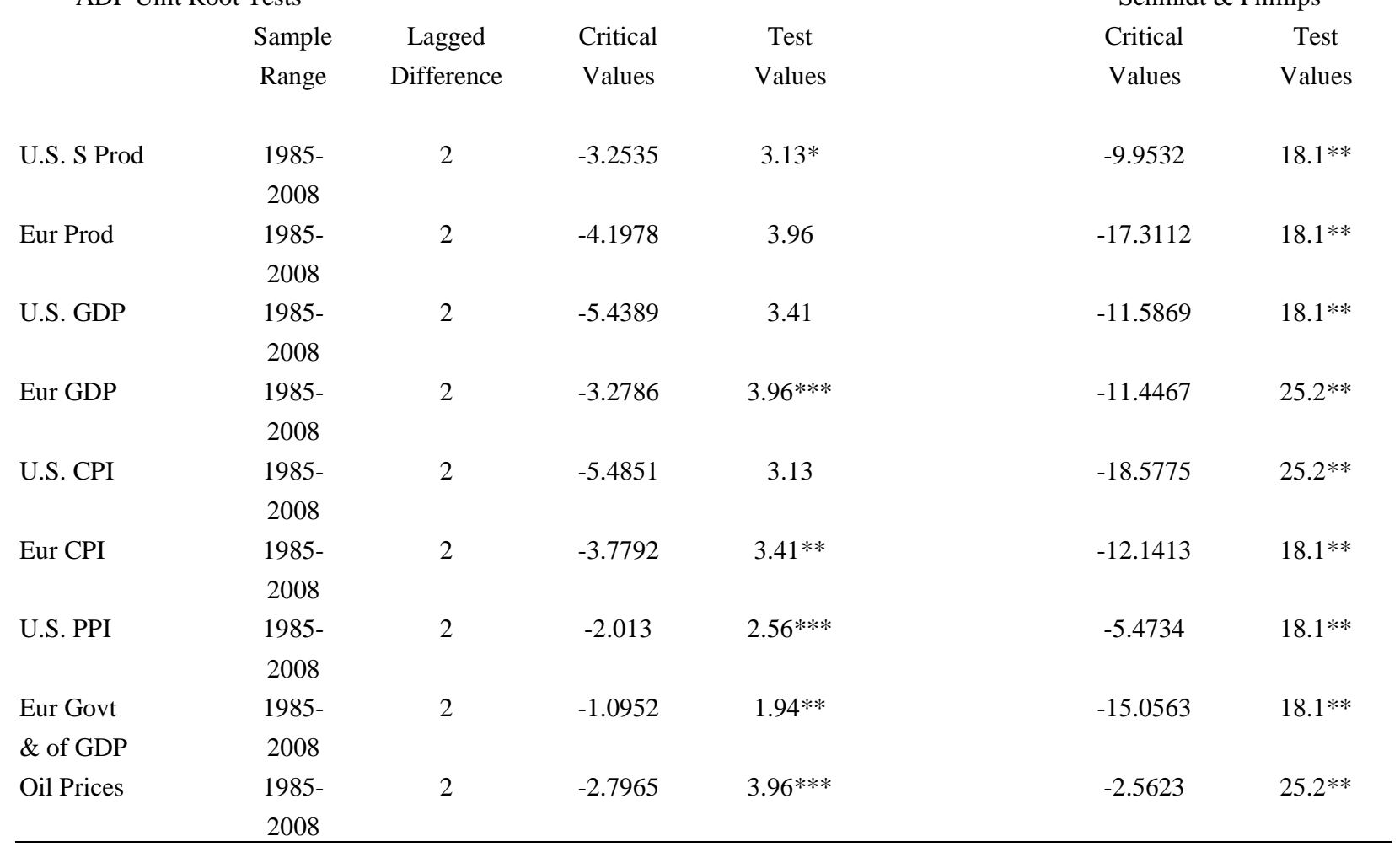

Table 2

\begin{tabular}{|c|c|c|c|c|}
\hline Cointegration & Period & Specification & LR Ratios & Critical Ratios \\
\hline Without Oil & & & & $\&$ Test Results \\
\hline U.S. Prod & 1985-2008 & 2 lags & 3.72 & $16.22 * * *$ \\
\hline Eur Prod & $1985-2008$ & 2 lags & 2.7 & $12.45 * *$ \\
\hline U.S. GDP & 1985-2008 & 2 lags & 2.23 & $12.53 * *$ \\
\hline Eur GDP & $1985-2008$ & 2 lags & 3.32 & $9.14 * *$ \\
\hline U.S. CPI & 1985-2008 & 2 lags & 10.59 & $12.45^{* *}$ \\
\hline Eur CPI & $1985-2008$ & 2 lags & 2.48 & $12.45 * *$ \\
\hline
\end{tabular}


Table 3

\begin{tabular}{|c|c|c|c|c|}
\hline Cointegration & Period & Specification & LR Ratios & Critical Ratios \\
\hline With Oil & & & & $\&$ Test Results \\
\hline U.S. Prod & $1985-2008$ & 2 lags & 15.34 & $25.73 * *$ \\
\hline Eur Prod & $1985-2008$ & 2 lags & 31.68 & $42.77 * *$ \\
\hline U.S. GDP & $1985-2008$ & 2 lags & 13.61 & $16.22 * * *$ \\
\hline Eur GDP & $1985-2008$ & 2 lags & 26.07 & $30.67 * * *$ \\
\hline U.S. S CPI & $1985-2008$ & 2 lags & 17.82 & $25.73 * *$ \\
\hline Eur CPI & $1985-2008$ & 2 lags & 16.62 & $30.67 * *$ \\
\hline
\end{tabular}

Table 4

Summary Correlations

Dependent Variable: Real Exchange Rate

\begin{tabular}{|c|c|c|c|}
\hline & Period & Test Results & t-values \\
\hline U.S. productivity & $1985-2008$ & -5.78 & 0.921 \\
\hline Eur productivity & $1985-2008$ & -5.52 & 0.45 \\
\hline U.S. GDP & $1985-2008$ & -1.19 & 0.731 \\
\hline Eur GDP & 1985-2008 & -4.35 & 0.787 \\
\hline
\end{tabular}


Chart 1

Euro Prod > USD/EURO Exchange Rate

Plat of Trme Serleg 1990.2-2008.2, T=49

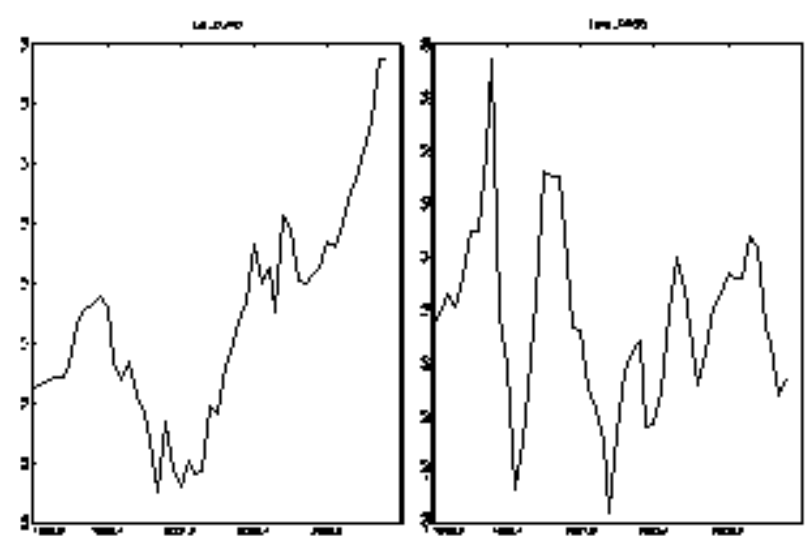

U.S. Prod > USD/EURO Exchange Rate

Plol of Time Serles 1960.2-200e.2, 7=69
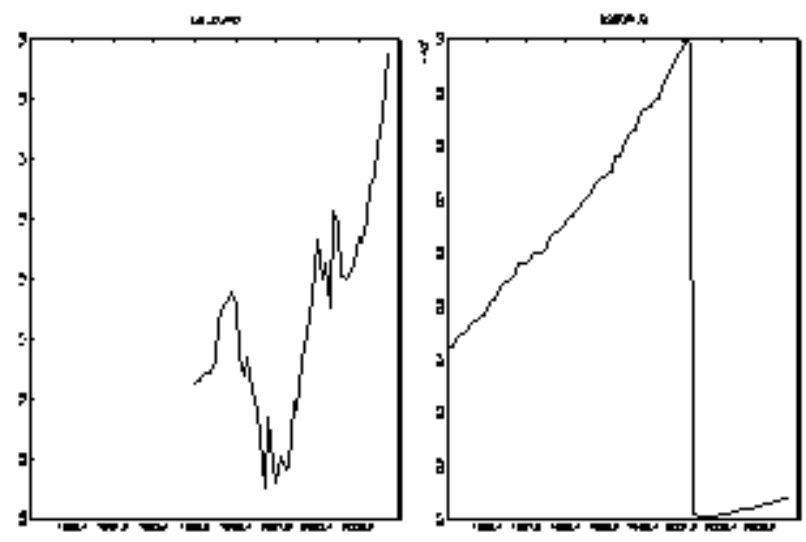
Chart 2

U.S. GDP > USD/EURO Exchange Rate

Dlol of Time Serles 1969.2-2000.2, 7=77

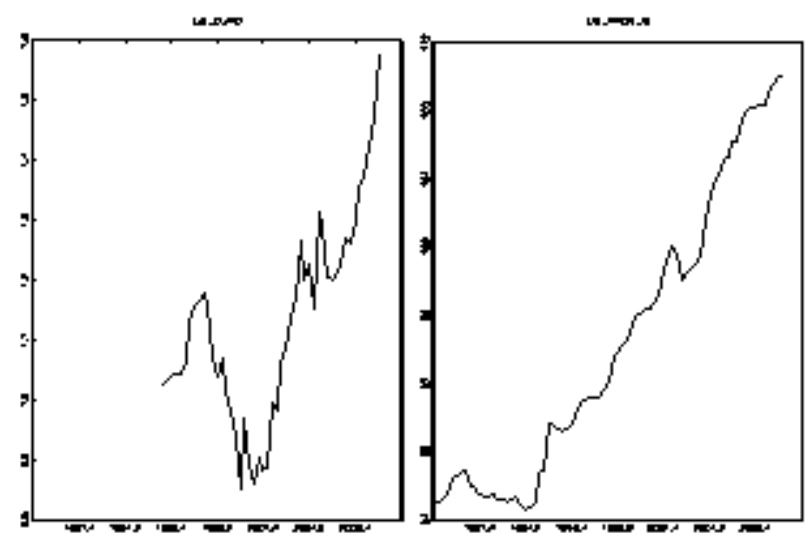

Euro GDP > USD/EURO Exchange Rate

Plol of Time serleg 1995.2-200e.2, 7=5

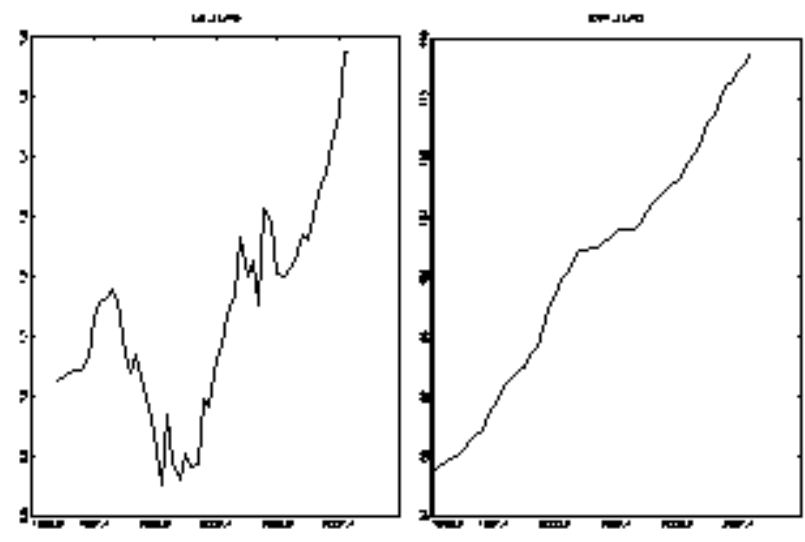




\section{Chart 3}

Euro GDP > U.S. /Euro Exchange Rate Mar

VECM Orthogonal Impulge Regponges GDP_EURO $\rightarrow$ LS_ELRO

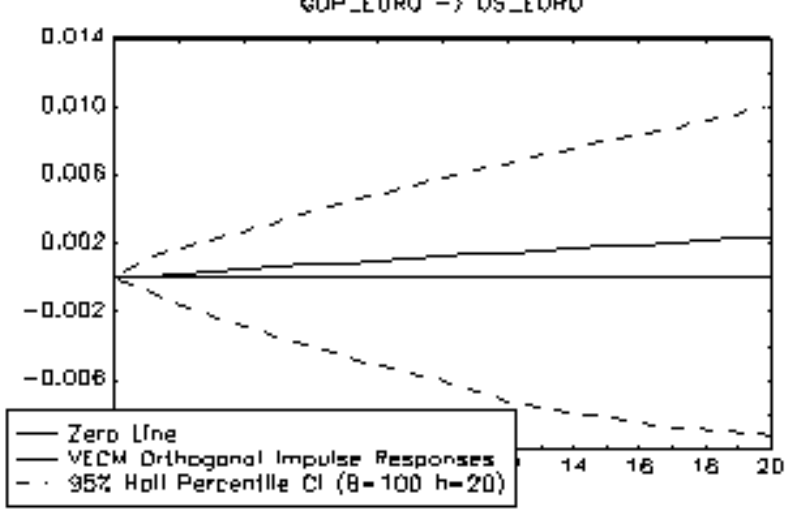

\section{U.S. GDP > US/Euro Exchange Rate}

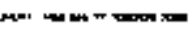

VECM Orthogonal Impulge Regponges USGDP_B -> US_EURЪ

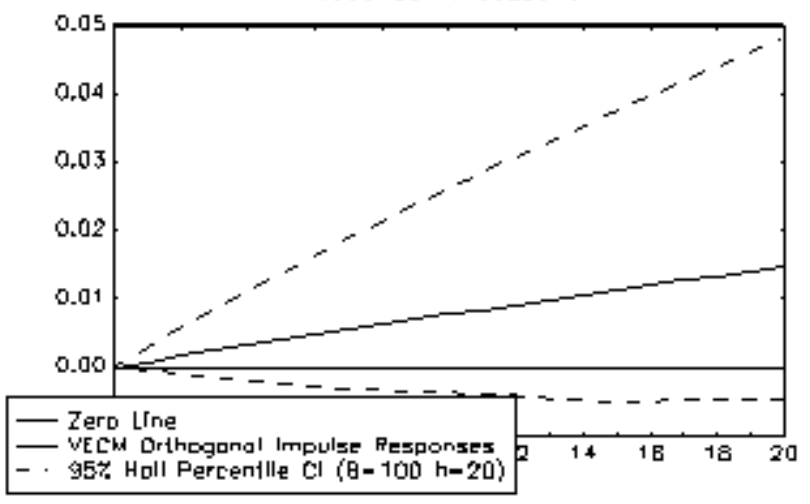


Chart 4

U.S. Prod > U.S. /Euro Exchange Rate $M=1, m=$

VEChd Forecogi Error Impulge Regponseg

US_PROO_E -> US_EURO

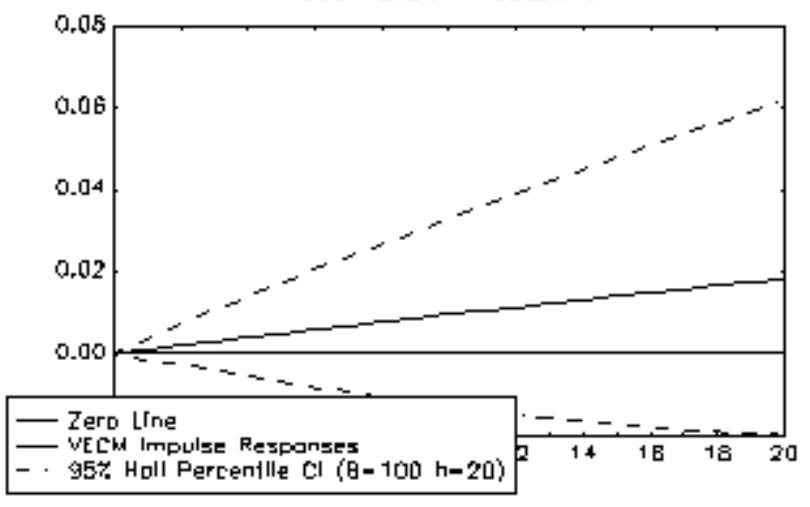

Euro Prod > U.S. /Euro Exchange Rate

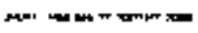

VECM Orthogonal Impulge Regponges

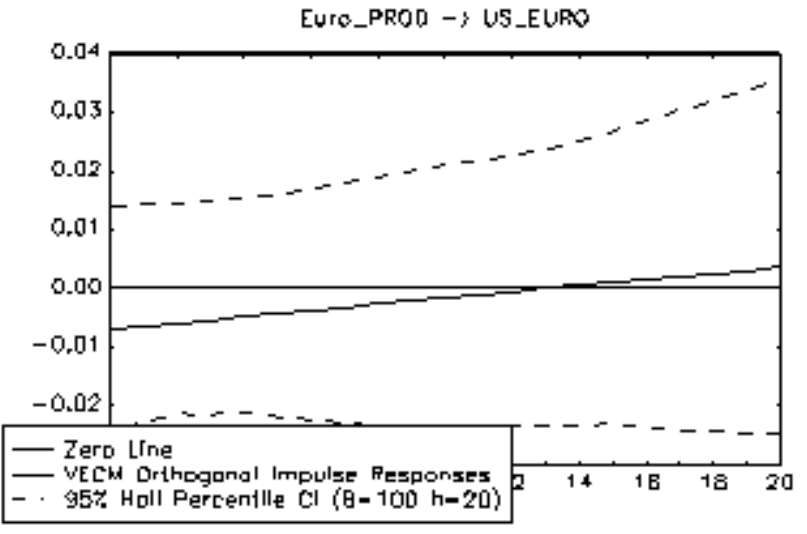

